\section{The CLEO assessment tool for pharmacist interventions}

\author{
Tommy Eriksson (1) 1,2
}

Pharmaceutical care to optimise medicines use and improve patients' health outcomes is a very important role of clinical pharmacists, for which medication review is the main activity. ${ }^{1}$ Several methods have been developed for documentation of pharmacist interventions (PIs) including processrelated and outcome-related indicators such as potential or actual impacts of drug-related problems. There has been no research describing a fully validated and generally accepted assessment tool that can be used for PIs.

In this issue of EJHP a French Working group presents the CLEO (CLinical, Economic, and Organisational) tool. ${ }^{2}$ This is a fully validated and generally accepted tool that can be used for assessing PIs. The tool produced inter- and intra-reliability scores of good to excellent, which is better than the majority of other published tools.

There is a need for pharmacists to document PIs in their daily activities as well as in research studies. These can include patient information, description and classification of drug-related problems, and suggestions for modifying prescriptions and physicians' acceptance of PIs. Assessing the impact on clinical improvement is needed to justify these activities, but also any economic and organisational benefits.

${ }^{1}$ Department of Biomedical Science, Malmö Universitet, Malmo, Sweden

${ }^{2}$ Biofilm - Research Center for Biointerfaces, Malmö Universitet, Malmo, Sweden

Correspondence to Professor Tommy Eriksson, Department of Biomedical Science, Malmö Universitet, 21119 Malmö, Sweden; tommy.eriksson@mau.se used further.
The development of the multidimensional CLEO tool is based on a review of previous models and tools for the assessment of PIs, ${ }^{3}$ and the clinical pharmacists' experience. Internal and external experts assessed in total 90 cases with PIs derived from daily practice. The assessment of the 'Clinical' dimension uses six levels: negative, null, minor, moderate, major, and avoiding a fatality. The 'Economic' and 'Organisational' dimensions have three levels: negative, null, positive. CLEO can be used both for daily practice and research. There are 54 possible threecomponent scores of the CLEO tool and the three dimensions are assessed separately. The authors state: "The external validation of the study suggested that individual clinical pharmacists can code their own interventions as they make them in daily practice, and their coding is likely to be consistent with other clinical pharmacists as experts or supervisors." Assessment of PIs by the CLEO tool may be a performance indicator and allows comparison of pharmacists' opinions and PIs' impacts among pharmacists, healthcare providers and different facilities, and may be a valuable tool in auditing them. It can be used to assess PIs with periodic assessment by others and also as training and learning activities based on the cases and evaluation by the experts. User satisfaction and acceptability with the tool was high and most raters spent no more than $1 \mathrm{~min}$ when rating the impact of one PI which demonstrated its feasible implementation.

We hope this tool finds acceptance for the benefit of pharmacy services, and is
Funding The authors have not declared a specific grant for this research from any funding agency in the public, commercial or not-for-profit sectors.

Competing interests None declared.

Patient consent for publication Not required.

Provenance and peer review Not commissioned; internally peer reviewed.

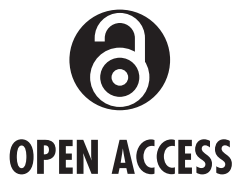

Open access This is an open access article distributed in accordance with the Creative Commons Attribution Non Commercial (CC BY-NC 4.0) license, which permits others to distribute, remix, adapt, build upon this work non-commercially, and license their derivative works on different terms, provided the original work is properly cited, an indication of whether changes were made, and the use is noncommercial. See: http://creativecommons.org/licenses/ by-nc/4.01.

(C) European Association of Hospital Pharmacists 2021. Re-use permitted under CC BY-NC. No commercial re-use. Published by BMJ.

A) Check for updates

To cite Eriksson T. Eur J Hosp Pharm 2021;28:181.

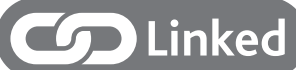

- http://dx.doi.org/10.1136/ejhpharm-2020-002642

Eur J Hosp Pharm 2021;28:181.

doi:10.1136/ejhpharm-2021-002882

ORCID iD

Tommy Eriksson http://orcid.org/0000-0001-94374334

\section{REFERENCES}

1 Hepler CD, Strand LM. Opportunities and responsibilities in pharmaceutical care. Am J Hosp Pharm 1990;47:533-43.

2 Vo HT, Charpiat B, Chanoine S, et al. CLEO: a multidimensional tool to assess clinical, economic and organisational impacts of pharmacists' interventions. Eur J Hosp Pharm 2021;28:193-200.

3 Vo T-H, Charpiat B, Catoire C, et al. Tools for assessing potential significance of pharmacist interventions: a systematic review. Drug Saf 2016;39:131-46. 